\title{
Acanthamoeba in Southeast Asia - Overview and Challenges
}

Chooseel Bunsuwansakul', Tooba Mahboob², Kruawan Hounkong ${ }^{3}$, Sawanya Laohaprapanon 4 , Sukhuma Chitapornpan ${ }^{5}$, Siriuma Jawjit ${ }^{4}$, Atipat Yasiri ${ }^{6}$, Sahapat Barusrux ${ }^{1}$, Kingkan Bunluepuech', Nongyao Sawangjaroen ${ }^{7}$, Cristina C. Salibay ${ }^{8}$, Chalermpon Kaewjai ${ }^{9}$, Maria de Lourdes Pereira ${ }^{10}$, Veeranoot Nissapatorn ${ }^{1, *}$

\begin{abstract}
${ }^{1}$ School of Allied Health, Southeast Asia Water Team (SEA Water Team) and World Union for Herbal Drug Discovery (WUHeDD), Walailak University,

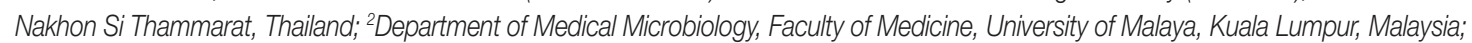
${ }^{3}$ Department of Microbiology, Princess of Naradhiwas University, Narathiwat, Thailand; ${ }^{4}$ School of Public Health, Walailak University, Nakhon Si Thammarat, Thailand; ${ }^{5}$ School of Energy and Environment, University of Phayao, Phayao, Thailand; ${ }^{6}$ Chulabhorn International College of Medicine, Thammasat University, Pathum Thani, Thailand; 'Department of Microbiology, Prince of Songkla University, Songkhla, Thailand; ${ }^{8} \mathrm{College}$ of Science and Computer Studies, De La Salle University-Dasmarinas, Dasmarinas City, Cavite, Philippines; ${ }^{9}$ Faculty of Medical Technology, Rangsit University,

Pathum Thani, Thailand; ${ }^{10}$ Department of Medical Sciences \& CICECO-Aveiro Institute of Materials, University of Aveiro, Aveiro, Portugal
\end{abstract}

\begin{abstract}
Acanthamoeba, one of free-living amoebae (FLA), remains a high risk of direct contact with this protozoan parasite which is ubiquitous in nature and man-made environment. This pathogenic FLA can cause sight-threatening amoebic keratitis (AK) and fatal granulomatous amoebic encephalitis (GAE) though these cases may not commonly be reported in our clinical settings. Acanthamoeba has been detected from different environmental sources namely; soil, water, hotspring, swimming pool, air-conditioner, or contact lens storage cases. The identification of Acanthamoeba is based on morphological appearance and molecular techniques using PCR and DNA sequencing for clinico-epidemiological purposes. Recent treatments have long been ineffective against Acanthamoeba cyst, novel anti-Acanthamoeba agents have therefore been extensively investigated. There are efforts to utilize synthetic chemicals, lead compounds from medicinal plant extracts, and animal products to combat Acanthamoeba infection. Applied nanotechnology, an advanced technology, has shown to enhance the anti-Acanthamoeba activity in the encapsulated nanoparticles leading to new therapeutic options. This review attempts to provide an overview of the available data and studies on the occurrence of pathogenic Acanthamoeba among the Association of Southeast Asian Nations (ASEAN) members with the aim of identifying some potential contributing factors such as distribution, demographic profile of the patients, possible source of the parasite, mode of transmission and treatment. Further, this review attempts to provide future direction for prevention and control of the Acanthamoeba infection.
\end{abstract}

Key words: Acanthamoeba, clinico-epidemiology, medicinal plant, molecular, nanotechnology, Southeast Asia

\section{INTRODUCTION}

Acanthamoeba spp. is one of pathogenic free-living amobae (FLA) along with Naegleria fowleri, Balamuthia mandrillaris, and Sappinia sp. which are potential to cause rare infection in central nervous system. These protozoan parasites are mostly found in natural soil and water bodies and immunocompro-

\footnotetext{
- Received 21 April 2019, revised 18 July 2019, accepted 18 July 2019.

*Corresponding author (nissapat@gmail.com)

(c) 2019, Korean Society for Parasitology and Tropical Medicine

This is an Open Access article distributed under the terms of the Creative Commons Attribution Non-Commercial License (http://creativecommons.org/licenses/by-nc/4.0) which permits unrestricted non-commercial use, distribution, and reproduction in any medium, provided the original work is properly cited.
}

mised patients as the main target [1]. Recently, Acanthamoeba spp. are recognized as increasing threat against contact lens wearers and healthy individuals also take some risks on amoebic keratitis (AK) [2]. Understanding on Acanthamoeba infections is therefore crucial but still limited in ASEAN countries even though studies on anti-Acanthamoeba agent do exist. Herein, an overview of Acanthamoeba was put in a nutshell as well as challenges on recent issues to encounter against this amoeba in our regional ASEAN countries including Brunei Darussalam, Cambodia, Indonesia, Lao People's Democratic Republic (PDR), Malaysia, Myanmar, the Philippines, Singapore, Thailand, and Vietnam. 


\section{ORIGIN OF ACANTHAMOEBA}

Acanthamoeba spp. is a centrosome-bearing, single-celled, flattened naked amoeba in Order Acanthopodida, Class Centramoebia, Phylum Discosea, Amoebozoa clade in Amorphea domain of Eukaryotic organisms [3]. Term "Acanth" in Greek means spike representing prominent sub-pseudopodia while "amoeba" means alteration like their appearance. The bacteriaphagocytosing protozoa is one of clinical FLA ubiquitous in nature soil and water bodies as well as man-made environment as a secondary decomposer. Ubiquity is implied by presence of antibodies in healthy individuals [4]. Acanthamoeba sp. was first recognized as contaminant of Cryptococcus pararoseus culture by Castellani in 1930 and named as Hartmannella castellanii and then a year later, Acanthamoeba spp. because of its double-walled cyst with irregular ectocyst appearance which is different from round and smooth cyst wall of Hartmannella spp. [5].

\section{BRIEF BIOLOGY OF ACANTHAMOEBA}

Acanthamoeba spp. appears in 2 forms of life cycle: trophozoite $(25-40 \mu \mathrm{m})$ and cyst $(13-20 \mu \mathrm{m})$. Trophozoite is an infective stage with amoeboid locomotion whilst cyst is a dormant stage against harsh environment such as temperature and $\mathrm{pH}$ imbalance, malnutrition, or presence of anti-Acanthamoeba agents [6]. One third of strength of cyst wall might come from polymer of glycosidic linkages between saccharides while another 2/3 are protein and other components, respectively [7]. Furthermore, the protist acts as potential reservoir or vector of human-pathogenic bacteria, fungi, or viruses while endosymbiont and Acanthamoeba-resistant organisms also are identified [8-10]. Recently, more than 25 species were recorded in NCBI taxonomy database and 20 genotypes were published which T4 is a major genotype associated with human infections $[9,11]$. For cultivation, xenic culture is obtained by using non-nutrient (Page's amoeba saline) or PYG (peptone 0.05\%, yeast extract $0.05 \%$, glucose $0.1 \%$ ) agar coated with living or killed bacteria (e.g., Escherichia coli) at $25-28^{\circ} \mathrm{C}$ in the dark for 2-3 days for trophozoite proliferation and 1-2 weeks for encystment while PYG (peptone 2\%, yeast extract $0.5 \%$, glucose $0.5 \%$ ) agar was used for axenic culture [12]. Culture in PYG medium at $4^{\circ} \mathrm{C}$ would be convenient method for long-term preservation at least 1-4 years [13].
EPIDEMIOLOGY OF ACANTHAMOEBA IN ASEANS

FLA, especially Acanthamoeba spp., occur worldwide and have a variety of habitats. Many studies have recorded the wide distribution in soil and water, with differing range of thermal tolerance (Table 1). They have been isolated in untreated natural freshwaters, like lakes, ponds, hot springs and waterfalls [14-17]; and brackish, seawaters, and ocean sediments [18]. They were also isolated from treated waters like domestic water systems, swimming pools, hydrotherapy pools, remedial spas, tap water and drinking water $[14,16,19,20]$. Unconventional water sources like sewage and aquaria were not spared with the presence of amoebas [18].

Aside from water, Acanthamoeba spp. were also present in different types of soils such as agricultural, garden and mining [21-23]. Acanthamoeba genotypes of infected cats and dogs were matched with dry soil and dust. [24]. Acanthamoeba-infected individuals can also be a source of the isolates of organism through sinuses, brain and corneal and skin specimens [22,25-27] and even in necrotic tissues [18].

The presence of Acanthamoeba spp. has impacted for the last decades because of the increasing cases of a rare condition $\mathrm{AK}$, a severe infection of the eye cornea associated with intense pain. This has been observed in contact lens wearer population [28]. It is believed that the cause of infection is due to the exposure of the eye to the Acanthamoeba-contaminated contact lens solutions. Acanthamoeba isolated from contact lens storage cases were confirmed [29]. Further, the usual spread of the contaminant is due to poor hygiene and maintenance of the lens; and exposure to contaminated water (swimming pool or other recreational waters) while wearing contact lenses.

However, the disease has also been reported in non-contact lens wearers $[18,26,27]$. This further affirms the possible contamination through direct contact to contaminated water and soil. The wide dispersal of Acanthamoeba onto the environment is due to the wind dispersal of its resistant form, the cysts. Likely that indoor ventilation system, blowing fan, air diffuser and other furniture contaminated with Acanthamoeba can be a cause of spreading indoor [30]. Thus, individuals who are not contact lens wearers but have been constantly exposed to dust particles and soil are also at high risk of infection [25]. It is also important to note that exposure to Acanthamoeba can be as simple as accidental splash of contaminated water to the face or bruised skin [14], making a fast and easy transmission. 


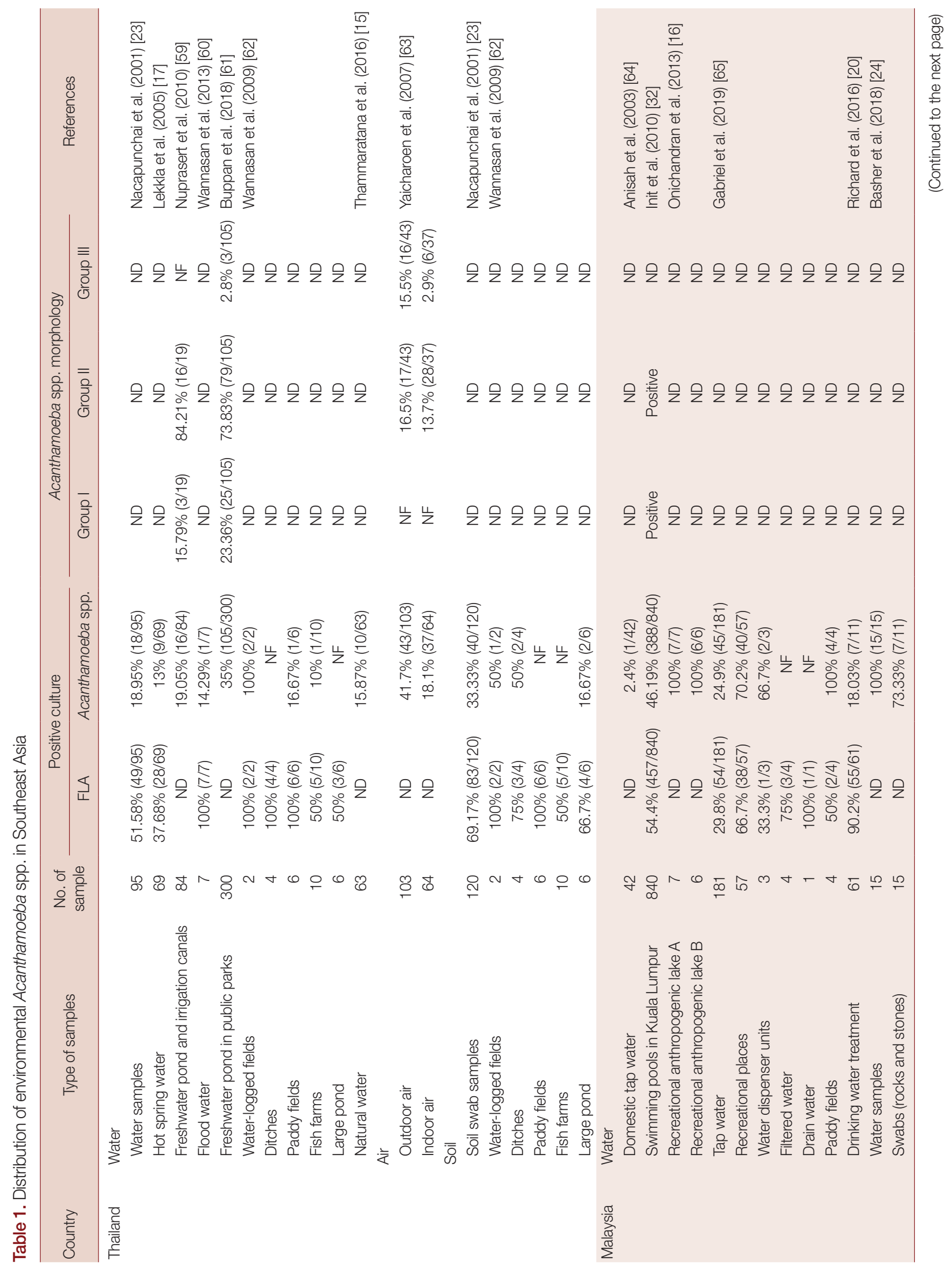




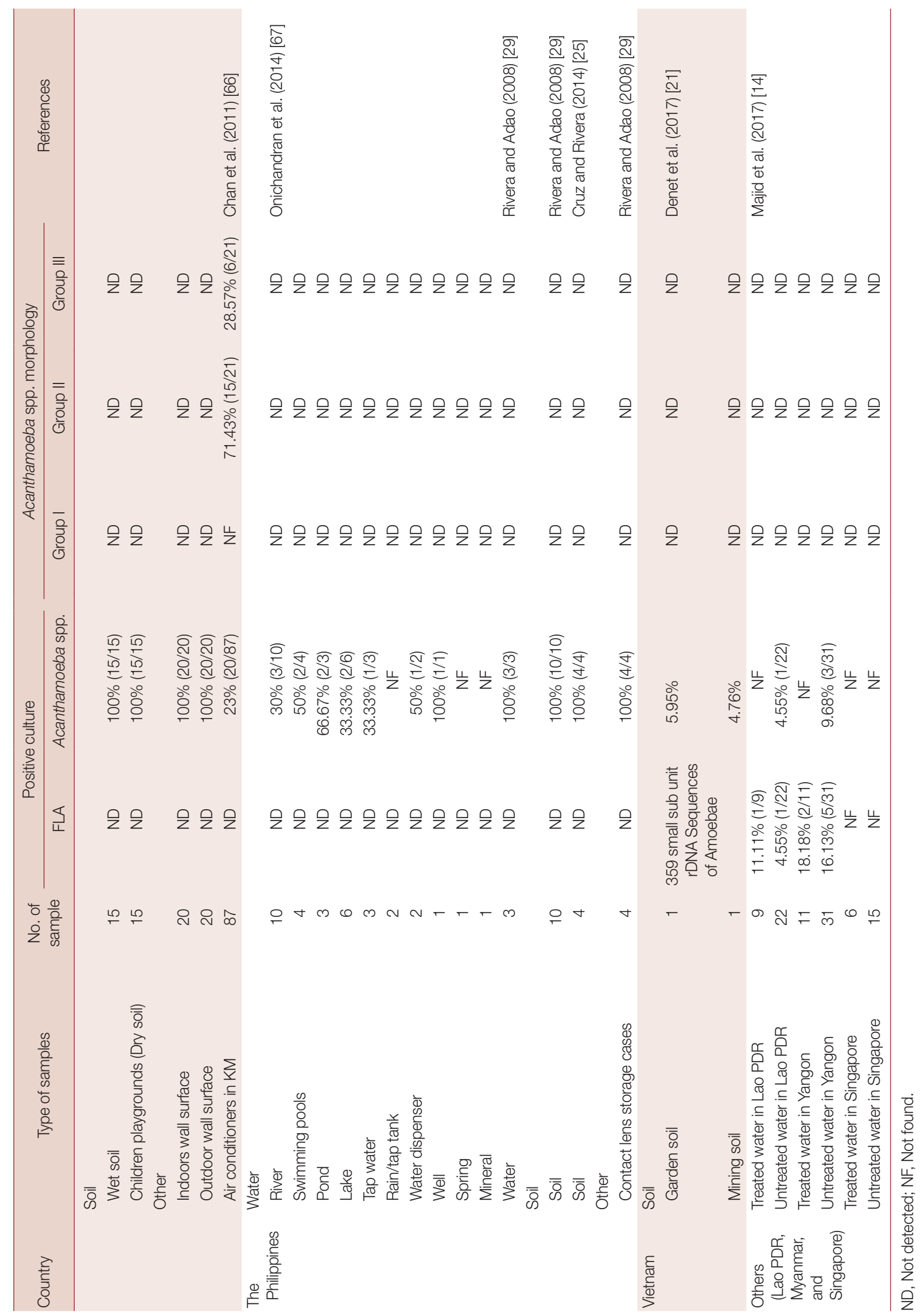




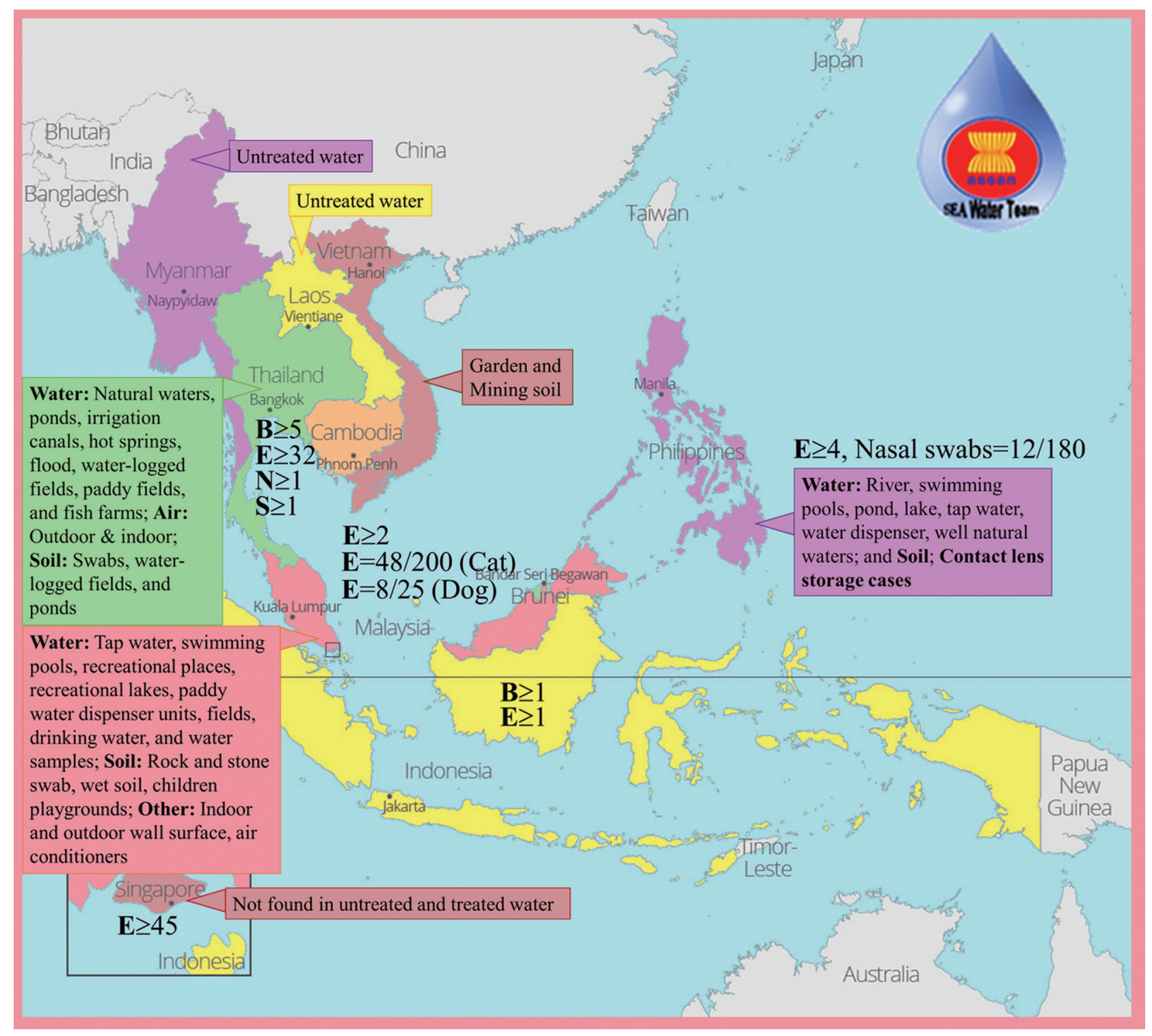

Fig. 1. Epidemiology and clinical cases of Acanthamoeba infection in Southeast Asia. B: Granulomatous amoebic encephalitis; E: Acanthamoeba keratitis; N: Acanthamoeba sinusitis; and S: Gastric acanthamoebiasis.

Ironically, with the many studies proving the presence of Acanthamoeba in different environmental media (soil, water and air), the dearth of information in Southeast Asian (ASEAN) countries is quite a concern, considering that the varying climatic conditions of the region is a favorable habitat for this organism which has an unusual geographic distribution [31].

The ASEAN countries' tropical condition, favorite tourist destinations during summer, consists of beaches, falls, and lakes are among the popular areas where more people involve with these outdoor activities. The congestion can increase risk of contamination with Acanthamoeba especially when the envi- ronment is dry during summer and dust particles can be easily spread. Likewise, resorts with swimming pools are occupied the entire summer with local and foreign tourists. Since resorts gain profit only during this time of the year, owners tend to maximize the use of the swimming pools which may compromise the proper cleanup of the swimming facility. This poses the risk to the swimmers, adding to the fact that Acanthamoeba can also be resistant to disinfectants [26,32].

The detection of Acanthamoeba in soil, water and air in other countries in ASEAN (Fig. 1), confirms that a continual contamination of the environment persists, and this poses a risk 
to people dependent on the soil and water for domestic activities, agricultural and farming occupation, and even for recreation. The lack of information in some countries (Cambodia and Brunei) does not mean the absence of Acanthamoeba-contaminated environment. Albeit, this may result to the inability of one country to control the spread of possible diseases associated with Acanthamoeba considering that this amoeba may also harbor pathogenic bacteria or fungi.

\section{CLINICAL SIGNIFICANCE AND DIAGNOSIS}

Potential pathogenicity of Acanthamoeba was first observed in monkey kidney cell in vitro as well as intracerebral/intraspinal inoculation in monkeys and intravenous/intranasal inoculation in mice [33,34]. First patient was recognized as GAE in 1972 and a year later, AK [35,36]. Acanthamoeba spp. are therefore considered as rare potential pathogen causing cutaneous lesions, sinusitis, $\mathrm{AK}, \mathrm{GAE}$, and disseminated form in human and prefer individuals with underlying diseases or immunocompromised host but AK was frequently reported in immunocompetent patients especially, contact lens wearers [37].

For AK, poor sanitation of contact lens wearer is a potential risk and corneal trauma seem required before trophozoite infection as well as eye secretion after contact lens wore might be preferred by Acanthamoeba [38,39]. Onset of AK is days to weeks with symptoms of tormenting eye pain, redness, photophobia, stromal infiltration leading to sight-threatening condition which are similar and misdiagnosed to Herpes simplex, bacterial or fungal keratitis $[39,40]$. AK is confirmed by presence of trophozoite with large nucleolus and contractile vacuoles as well as pseudopodia and transparent protrusions of Acanthopodia from corneal scrapings or biopsies under direct microscopy with several stains. Encystment on non-nutrient agar (NNA) and nucleic acid amplification testing are further investigated for species identification and genotyping, respectively. Taxonomic identification mainly investigated by cyst morphology under microscope [41] and a hypervariable sequence part of $18 \mathrm{~S}$ small subunit rDNA gene called ASA.S1 by Acanthamoeba-specific primers: JDP1 and JDP2 (amplicon size 467 bps for Neff strain of A. castellanii accession number M13435.1) [42]. Extended or almost complete of $18 \mathrm{~S}$ rDNA amplicon size provide better solution for genotyping [11,42]. Pathogen broad-spectrum and most effective anti-Acanthamoeba agents against two forms, $0.02 \%$ polyhexamethylene biguanide (PHMB) or chlorhexidine, still need antibacterial, antifungal, or aromatic diamidines combination because of resistance of cyst form and PHMB is toxic to human corneal cells [40].

For GAE, a very rare condition, is opportunistic and fatal infection with onset of weeks to months mostly in immunocompromised patients, especially HIV/AIDS patients through skin breaks, respiratory tract, and olfactory epithelium. GAE patient will encounter with neurological signs such as confusion, headache, and stiff neck as well as psychological change, e.g. irritability generally like other brain infections due to effect of edema, necrosis, and hemorrhages in infected part of brain [43]. To confirm GAE, microscopy and culture from CSF remain gold standard methods used after neuroimaging detection of brain lesions while indirect immunofluorescence on tissue and multiplex real-time PCR assay are available [44]. Late/missed diagnosis, blood-brain barrier crossing of antimicrobial, drug side effects, drug combination are still an issue on GAE treatment and only few patients were cured $[45,46]$.

There are many reports on Acanthamoeba infection in ASEAN countries (Table 2). Most infections are AK with contact lens while cases of GAE is rare. Notably, Acanthamoeba can be involved with gastric ulcer and sinusitis and found from nasal swab from healthy individuals and corneal swab from infected animal (Table 2). Undeniably, exposure to soil and contaminated water are potential risk but underlying disease might be another one factor for the infections. Misdiagnosis and delay in diagnosis are common among patients leading to permanent vision blurriness because of injured cornea or deeper layers for AK and death for GAE. These problems are still insolvable till date. Rapid and accurate prognosis is therefore an urgent need for Acanthamoeba infection.

\section{CURRENT CHALLENGES AND FUTURE PERSPECTIVES}

Contact with Acanthamoeba spp. is common. Immunocompromised patients should realize this risk and avoid exposure to, especially, natural soil and water bodies even though it is a rare disease but GAE is fatal and AK is vision-threatening [6]. Moreover, no specifically therapeutic course is available for Acanthamoeba spp. infections, in case of GAE. However, commercial drugs for AK are highly toxic due to prolonged treatment duration as well as diagnosis and combination of treatments depends on medical expertise of physician and availability of resources $[6,47]$. The statement diagnostic is challenge that a new molecular technology can be used in Acan- 


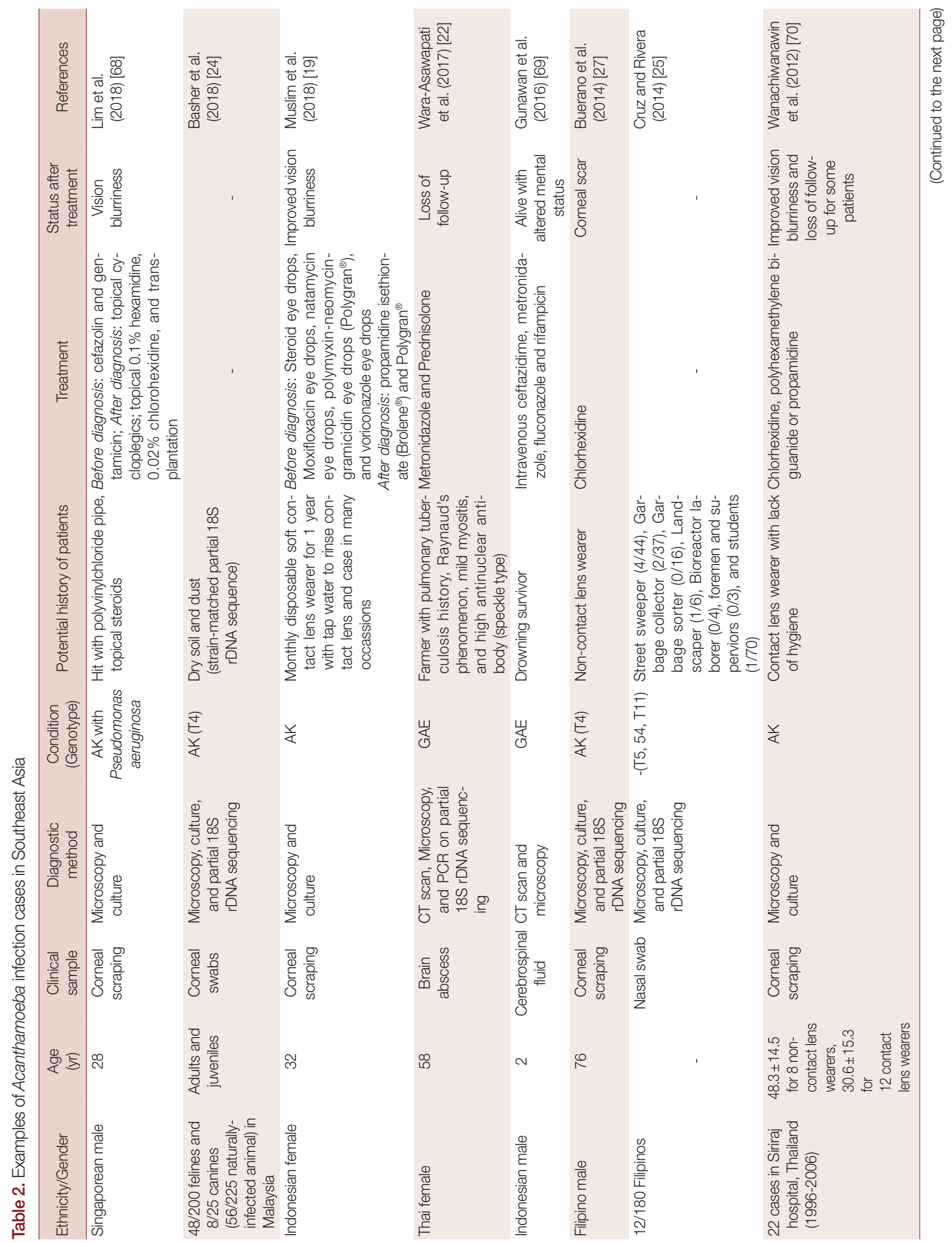




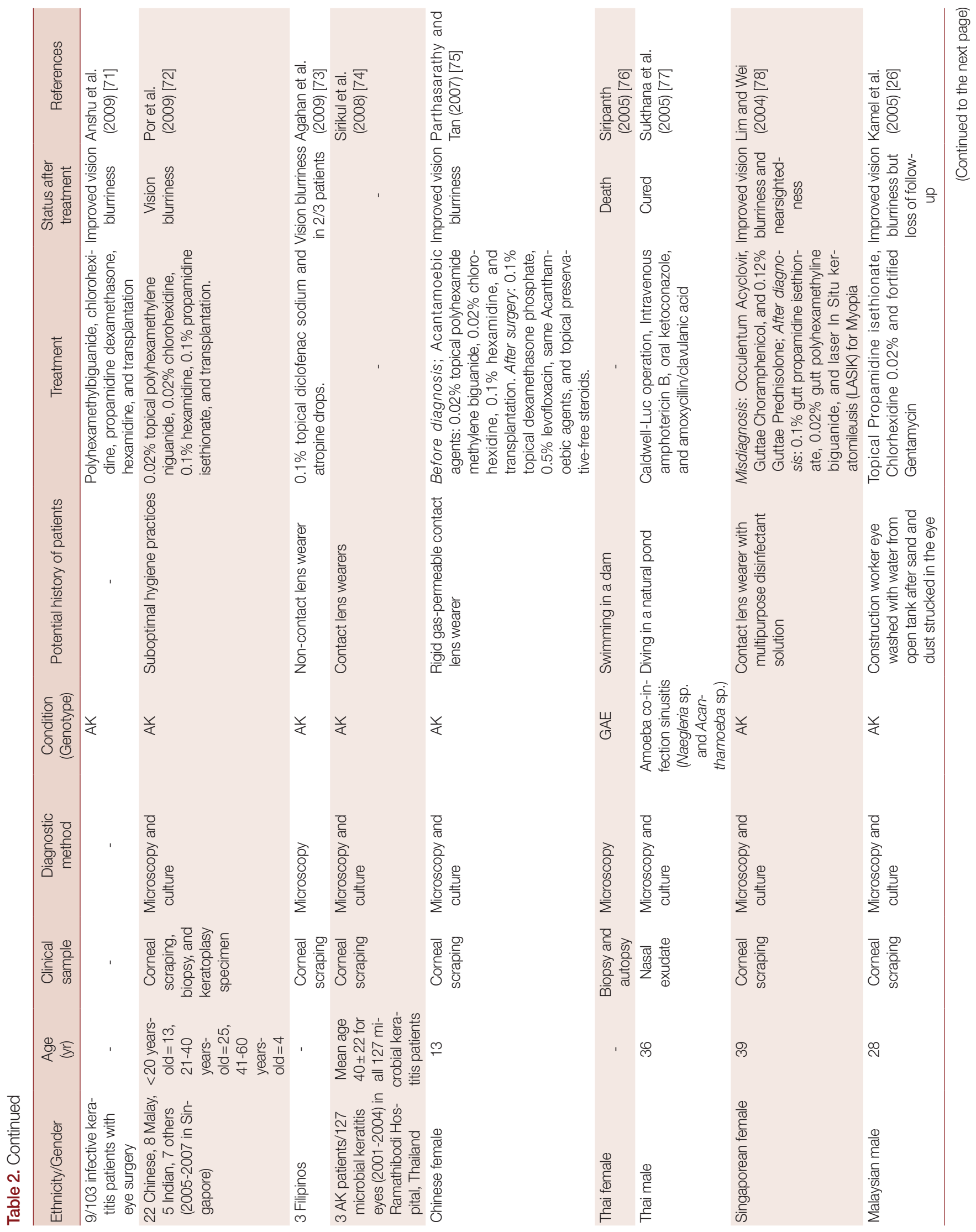




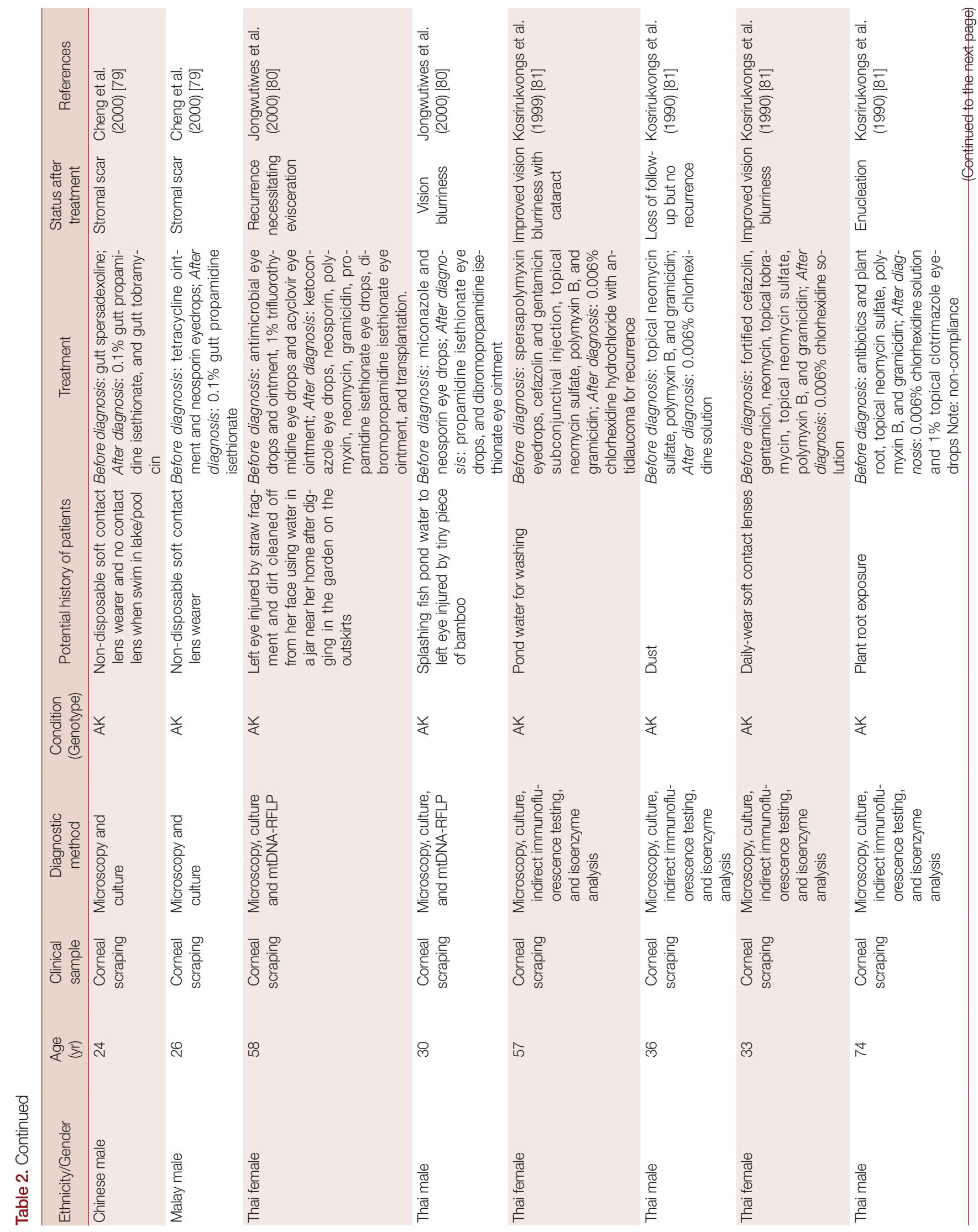




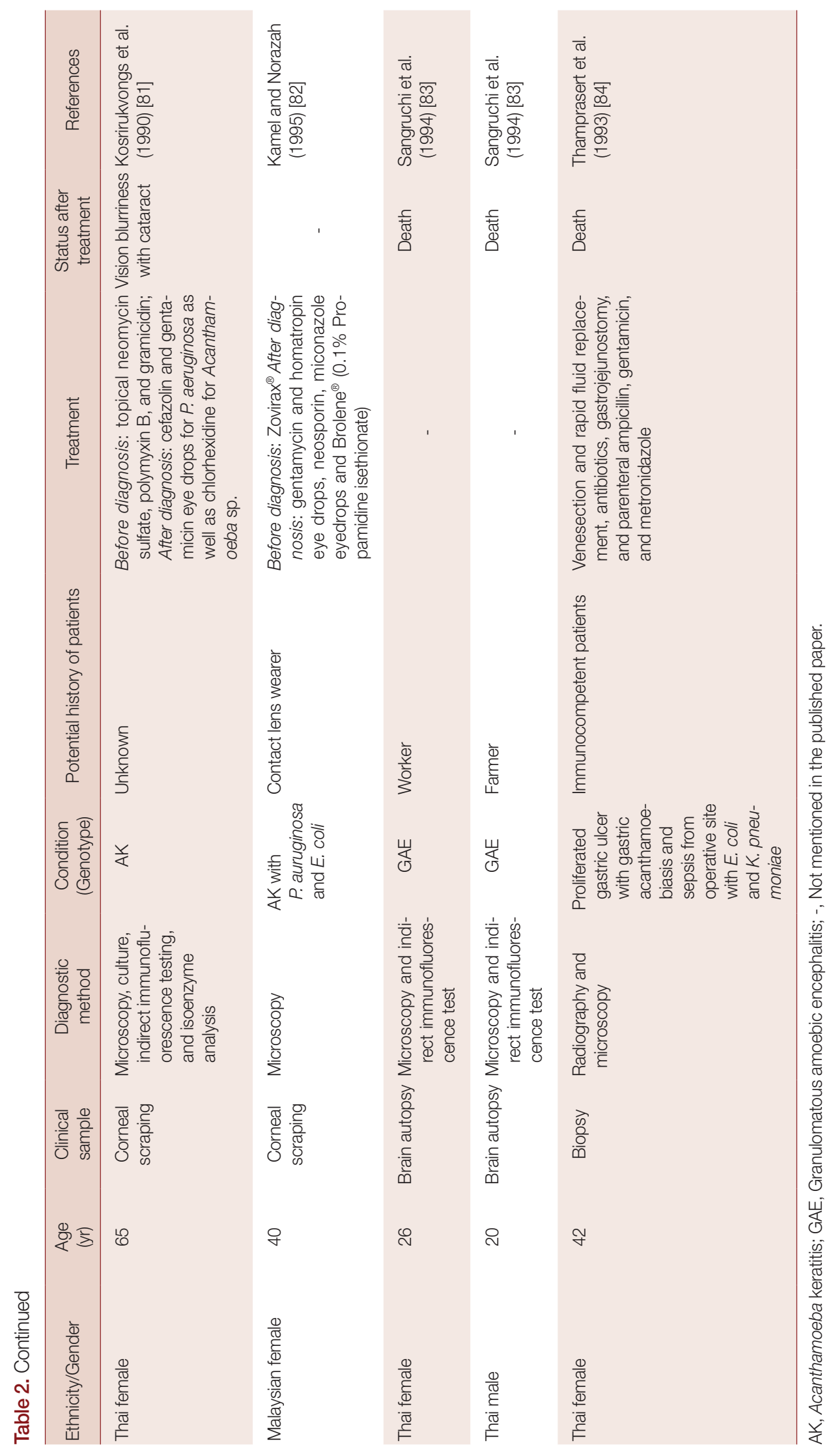




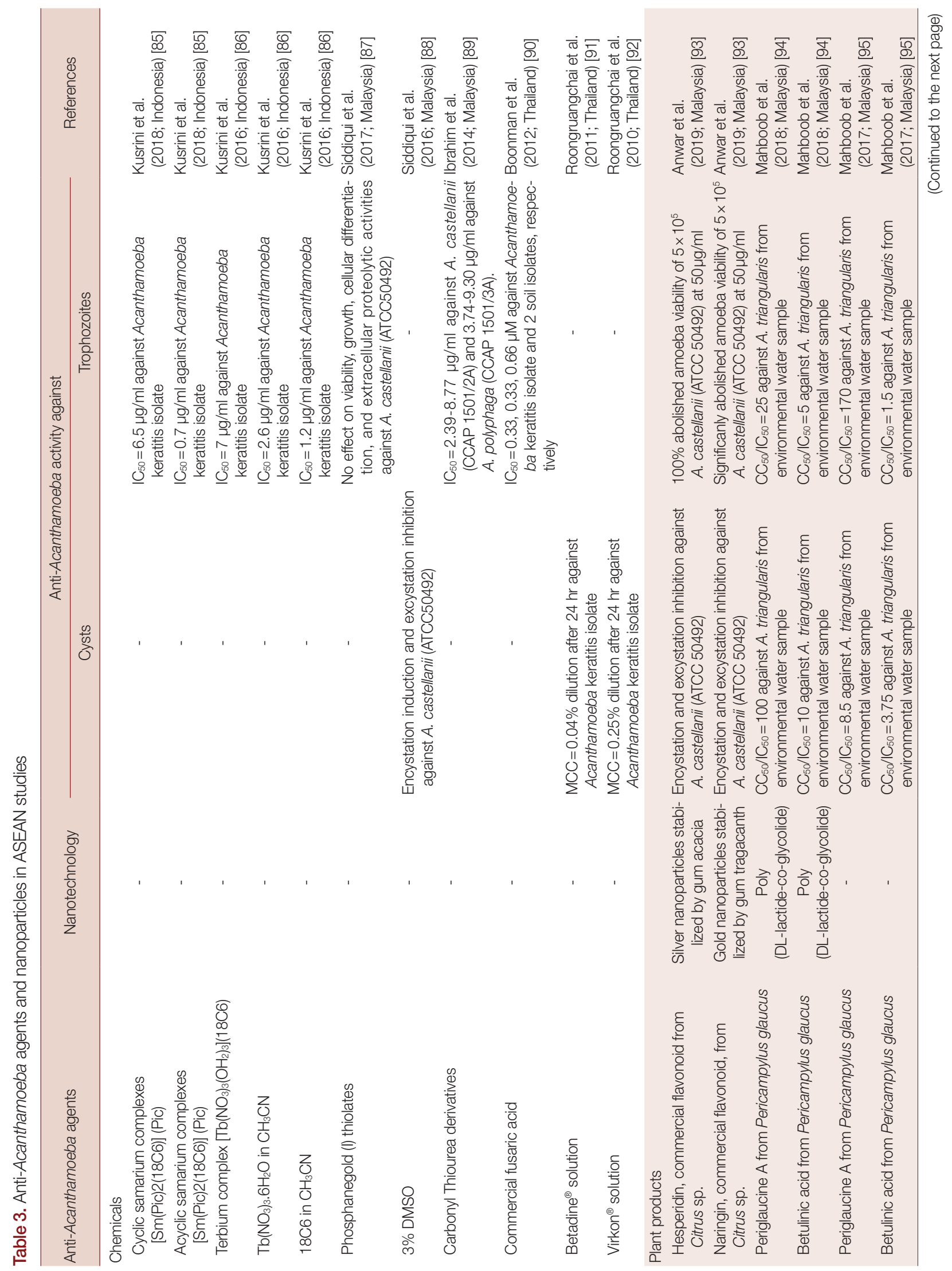




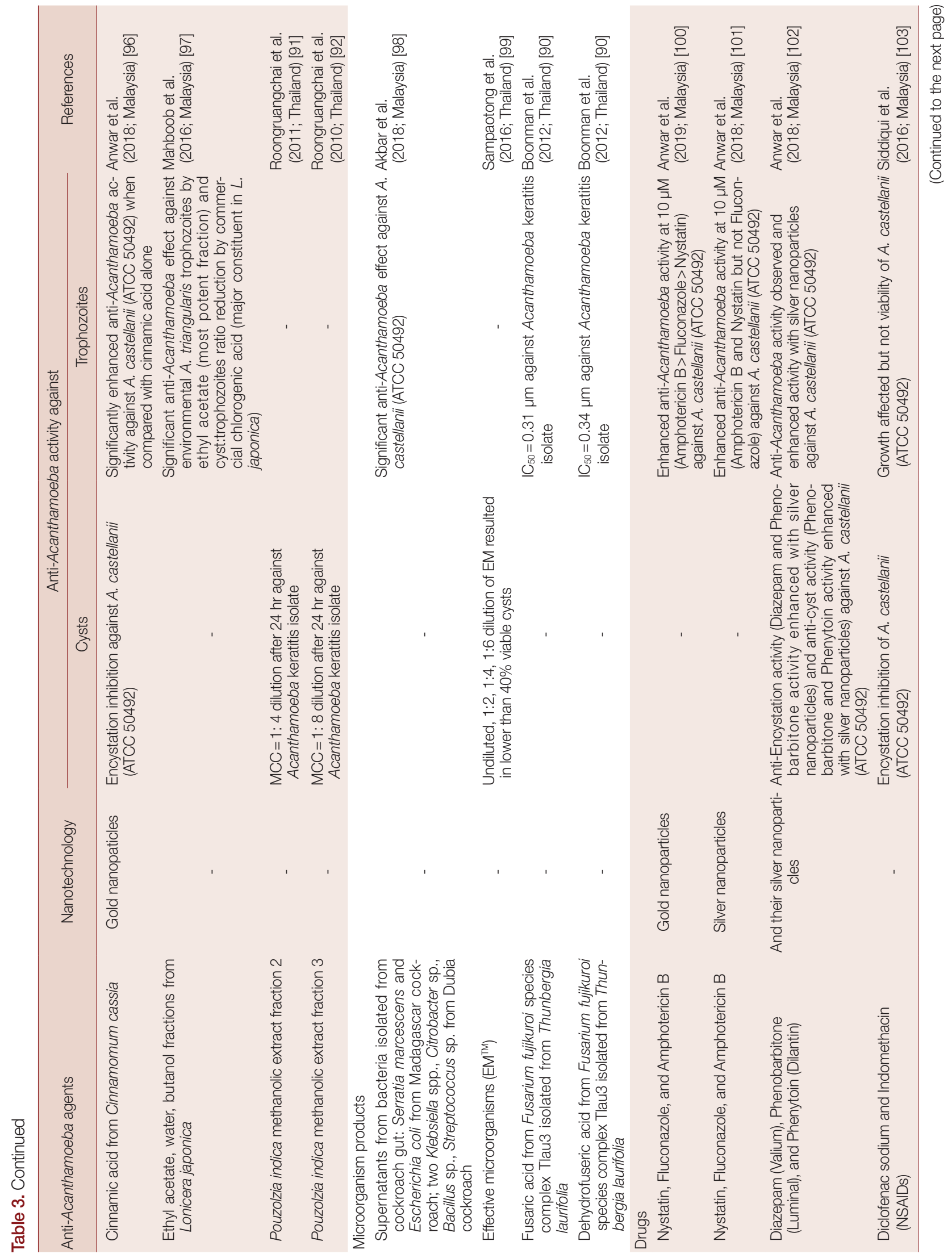




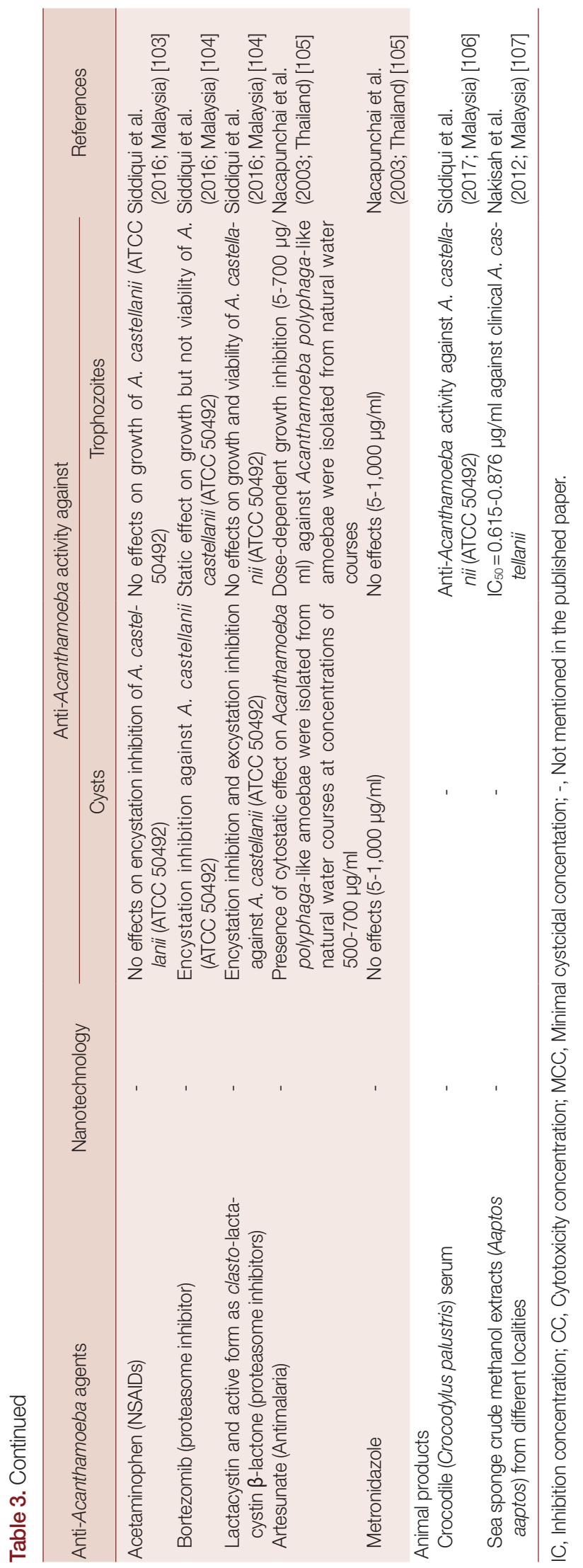

thamoeba detection and monitoring system to understand these amoebic infections and diagnostic approaches. So far, the gold standard of Acanthamoeba laboratory testing has been cultured on NNA overlaid with E. coli and PYG medium for axenic culture. A modern technique has been applied as far as the laboratory diagnosis is concerned. This can provide a better routine diagnosis especially using molecular-based intervention such as PCR and MALDI-TOF/MS [5]. It is important because mistaken or late diagnosis has been usually reported due to poor prognosis leading to worsening clinical symptoms and subsequently under postmortem diagnosis [48,49]. Moreover, Acanthamoeba spp. are potential Trojan horse of humanpathogenic viruses, infectious bacteria, and fungi which might be one way of disease spread and gene transfer [10]. Early detection technique is needed as well as physician should be aware of Acanthamoeba infection through patient interview and history taking [50,51]. Unfortunately, most patients also come up with lesion in brain for GAE which most of the cases are too late to be cured whilst AK are mainly associated with contact lens wearer and immunocompetent patients are basically affected [52-54].

Hygiene and proper contact lens usage is a critical point of care which ophthalmologist should pass on knowledge of appropriate usage of contact lens [55]. Most disinfectant solutions for contact lens are ineffective against Acanthamoeba cyst which is rich with cellulose structure [56]. Effort on novel antiAcanthamoeba agents therefore focus on cyst form or other potential target sites [7]. Biology of Acanthamoeba spp. should be studied to guide action of desired anti-Acanthamoeba agents which have been identified [57]. In ASEAN nations, AntiAcanthamoeba activity has been investigated among humanmade chemicals, plant extracts, microbial metabolites, antiAcanthamoeba side effect of drugs, and animal products which nanoparticles are attractive antimicrobial agent delivery technology to enhance the activity of these anti-Acanthamoeba agents (Table 3). However, these anti-Acanthamoeba agents were tested only in vitro. Blood-brain barrier is another challenge for anti-Acanthamoeba agents to pass through for the treatment of GAE [58]. There is a long road lying ahead for in vivo experiment and clinical application in ASEAN nations. In fact, Southeast Asia (ASEAN) is a gigantic resource of medicinal plants and bioactive agents. Interestingly, the only PHARM database is available at the Faculty of Pharmacy, Mahidol University, Thailand in which more than 1,000 collections of Thai medicinal plants were recorded (http://www.medplant.mahi- 
dol.ac.th/pharm/search.asp: March 13, 2019). It is therefore noteworthy to strongly recommend for more research works that should be further explored on the plants-based medicinal therapy for severe or deadly infections with Acanthamoeba spp.

\section{ACKOWLEDGMENTS}

This work is under the project entitled of "Medicinal underexploited Thai native plants against Acanthamoeba, Leishmania donovani, and Plasmodium falciparum - Toward South East Asia collaboration initiative (Grant No. 040226) supported by The Royal Patronage of Her Royal Highness Princess Maha Chakri Sirindhorn". We are also grateful to the Project CICECO-Aveiro Institute of Materials, FCT Ref. UID/CTM/50011/2019.

\section{CONFLICT OF INTEREST}

The authors declare no conflict of interest related to this study.

\section{REFERENCES}

1. Trabelsi H, Dendana F, Sellami A, Sellami H, Cheikhrouhou F, Neji S, Makni F, Ayadi A. Pathogenic free-living amoebae: epidemiology and clinical review. Pathol Biol 2012; 60: 399-405.

2. Juarez MM, Tartara LI, Cid AG, Real JP, Bermudez JM, Rajal VB, Palma SD. Acanthamoeba in the eye, can the parasite hide even more? Latest developments on the disease. Cont Lens Anterior Eye 2018; 41: 245-251.

3. Adl SM, Bass D, Lane CE, Lukeš J, Schoch CL, Smirnov A, Agatha S, Berney C, Brown MW, Burki F, Cárdenas P, Čepička I, Chistyakova L, Del Campo J, Dunthorn M, Edvardsen B, Eglit Y, Guillou L, Hampl V, Heiss AA, Hoppenrath M, James TY, Karnkowska A, Karpov S, Kim E, Kolisko M, Kudryavtsev A, Lahr DJG, Lara E, Le Gall L, Lynn DH, Mann DG, Massana R, Mitchell EAD, Morrow C, Park JS, Pawlowski JW, Powell MJ, Richter DJ, Rueckert S, Shadwick L, Shimano S, Spiegel FW, Torruella G, Youssef N, Zlatogursky V, Zhang Q. Revisions to the classification, nomenclature, and diversity of eukaryotes. J Eukaryot Microbiol 2019; 66: 4-119.

4. Cursons RT, Brown TJ, Keys EA, Moriarty KM, Till D. Immunity to pathogenic free-living amoebae: role of humoral antibody. Infect Immun 1980; 29: 401-407.

5. Khan NA. Acanthamoeba Biology and pathogenesis. University of Nottingham, UK. Caister Academic Press. Act Parasit 2009; 54: $1230-2821$.

6. Marciano-Cabral F, Cabral G. Acanthamoeba spp. as agents of disease in humans. Clin Microbiol Rev 2003; 16: 273-307.

7. Anwar A, Khan NA, Siddiqui R. Combating Acanthamoeba spp. cysts: what are the options? Parasit Vectors 2018; 11: 26.

8. Scheid P, Schwarzenberger R. Acanthamoeba spp. as vehicle and reservoir of adenoviruses. Parasitol Res 2012; 111: 479-485.

9. Siddiqui R, Khan NA. Biology and pathogenesis of Acanthamoeba. Parasit Vectors 2012; 5: 6.

10. Guimaraes AJ, Gomes KX, Cortines JR, Peralta JM, Peralta RH. Acanthamoeba spp. as a universal host for pathogenic microorganisms: One bridge from environment to host virulence. Microbiol Res 2016; 193: 30-38.

11. Corsaro D, Walochnik J, Köhsler M, Rott MB. Acanthamoeba misidentification and multiple labels: redefining genotypes T16, T19, and T20 and proposal for Acanthamoeba micheli sp. nov.(genotype T19). Parasitol Res 2015; 114: 2481-2490.

12. Schuster FL. Cultivation of pathogenic and opportunistic freeliving amebae. Clin Microbiol Rev 2002; 15: 342-354.

13. Axelsson-Olsson D, Olofsson J, Ellström P, Waldenström J, Olsen B. A simple method for long-term storage of Acanthamoeba species. Parasitol Res 2009; 104: 935-937.

14. Majid MA, Mahboob T, Mong BG, Jaturas N, Richard RL, TianChye T, Phimphila A, Mahaphonh P, Aye KN, Aung WL, Chuah J, Ziegler AD, Yusiri A, Sawangjaroen N, Lim YA, Nissapatorn V. Pathogenic waterborne free-living amoebae: An update from selected Southeast Asian countries. PLoS One 2017; 12: e0169448.

15. Thammaratana $T$, Laummaunwai $P$, Boonmars $T$. Isolation and identification of Acanthamoeba species from natural water sources in the northeastern part of Thailand. Parasitol Res 2016; 115: 1705-1709.

16. Onichandran S, Kumar T, Lim YA, Sawangjaroen N, Andiappan H, Salibay CC, Chye TT, Ithoi I, Dungca JZ, Sulaiman WY, Ling LY, Niassapatorn V. Waterborne parasites and physico-chemical assessment of selected lakes in Malaysia. Parasitol Res 2013; 112: 4185-4191.

17. Lekkla A, Sutthikornchai C, Bovornkitti S, Sukthana Y. Free-living ameba contamination in natural hot springs in Thailand. Southeast Asian J Trop Med Public Health 2005; 36: 5.

18. Visvesvara GS, Stehr-Green JK. Epidemiology of free-living ameba infections. J Protozool 1990; 37: 25s-33s

19. Muslim F, Sitompul R, Edwar L. Acanthamoeba keratitis: a challenge in diagnosis and the role of amniotic membrane transplant as an alternative therapy. Med J Indones 2018; 27: 299303.

20. Richard R, Ithoi I, Abd Majid M, Wan Sulaiman W, Tan T, Nissapatorn V, Lim Y. Monitoring of waterborne parasites in two drinking water treatment plants: a study in Sarawak, Malaysia. Int J Environ Res Public Health 2016; 13: 641

21. Denet E, Coupat-Goutaland B, Nazaret S, Pélandakis M, FavreBonté S. Diversity of free-living amoebae in soils and their associated human opportunistic bacteria. Parasitol Res 2017; 116: 3151-3162.

22. Wara-Asawapati S, Intapan PM, Chotmongkol V. Acanthamoeba Brain abscess confirmed by molecular identification. Am J Trop Med Hyg 2017; 97: 307.

23. Nacapunchai D, Kino H, Ruangsittichai C, Sriwichai P, Ishih A, 
Terada M. A brief survey of free-living amebae in Thailand and Hamamatsu district, Japan. Southeast Asian J Trop Med Public Health 2001; 32: 179-182.

24. Basher MHA, Ithoi I, Mahmud R, Abdulsalam AM, Foead AI, Dawaki S, Atroosh WM, Nissapatorn V, Abdullah WO. Occurrence of Acanthamoeba genotypes in Central West Malaysian environments. Acta Trop 2018; 178: 219-228.

25. Cruz AR, Rivera WL. Genotype analysis of Acanthamoeba isolated from human nasal swabs in the Philippines. Asian Pac J Trop Med 2014; 7 (suppl): 74-78.

26. Mohamed Kamel AG, Faridah H, Yusof S, Norazah A, Nakisah MA. A case of non-contact lens related Acanthamoeba keratitis in Malaysia. Malays J Microbiol 2005; 1: 58-60.

27. Buerano CC, Trinidad AD, Fajardo LS, Cua IY, Baclig MO, Natividad FF. Isolation of Acanthamoeba genotype T4 from a noncontact lens wearer from the Philippines. Trop Med Int Health 2014; 42: 145-147.

28. Ibrahim YW, Boase DL, Cree IA. Factors affecting the epidemiology of Acanthamoeba keratitis. Ophthalmic Epidemiol 2007; 14: 53-60.

29. Rivera WL, Adao DE. Identification of the 18S-ribosomal-DNA genotypes of Acanthamoeba isolates from the Philippines. Ann Trop Med Parasitol 2008; 102: 671-677.

30. Ooi SS, Mak JW, Chen DK, Ambu S. The correlation of Acanthamoeba from the ventilation system with other environmental parameters in commercial buildings as possible indicator for indoor air quality. Ind Health 2017; 55: 35-45.

31. Joslin CE, Tu EY, McMahon TT, Passaro DJ, Stayner LT, Sugar J. Epidemiological characteristics of a Chicago-area Acanthamoeba keratitis outbreak. Am J Ophthalmol 2006; 142: 212-217.

32. Init I, Lau YL, Fadzlun AA, Foead AI, Neilson RS, Nissapatorn V. Detection of free living amoebae, Acanthamoeba and Naegleria, in swimming pools, Malaysia. Trop Biomed 2010; 27: 566-577.

33. Culbertson CG, Smith JW, Minner JR. Acanthamoeba: observations on animal pathogenicity. Science 1958; 127: 1506.

34. Jahnes WG, Fullmer HM, Li CP. Free living amoebae as contaminants in monkey kidney tissue culture. Proc Soc Exp Biol Med 1957; 96: 484-488.

35. Jager BV, Stamm WP. Brain abscesses caused by free-living amoeba probably of the genus Hartmannella in a patient with Hodgkin's disease. Lancet 1972; 300: 1343-1345.

36. Nagington J, Watson PG, Playfair TJ, McGill J, Jones B, Steele AM. Amoebic infection of the eye. Lancet 1974; 304: 1537 1540.

37. Schuster FL, Visvesvara GS. Free-living amoebae as opportunistic and non-opportunistic pathogens of humans and animals. Int J Parasitol 2004; 34: 1001-1027.

38. Niederkorn JY, Alizadeh H, Leher H, McCulley JP. The pathogenesis of Acanthamoeba keratitis. Microbes Infect 1999; 1: 437443.

39. Khan NA. Acanthamoeba: biology and increasing importance in human health. FEMS Microbiol Rev 2006; 30: 564-595.

40. Lorenzo-Morales J, Khan NA, Walochnik J. An update on Acan- thamoeba keratitis: diagnosis, pathogenesis and treatment. Parasite $2015 ; 22: 10$.

41. Page FC. A New Key to Freshwater and Soil Gymna-moebae with instructions for cultivation. Freshwater Biological Association. Cumbria, UK. 1988, pp 1-122.

42. Schroeder JM, Booton GC, Hay J, Niszl IA, Seal DV, Markus MB, Fuerst PA, Byers TJ. Use of subgenic 18S ribosomal DNA PCR and sequencing for genus and genotype identification of acanthamoebae from humans with keratitis and from sewage sludge. J Clin Microbiol 2001; 39: 1903-1911.

43. Duggal SD, Rongpharpi SR, Duggal AK, Kumar A, Biswal I. Role of Acanthamoeba in granulomatous encephalitis: a review. J Infect Dis Immune Ther 2017; 1: 2.

44. Qvarnstrom Y, Visvesvara GS, Sriram R, da Silva AJ. Multiplex real-time PCR assay for simultaneous detection of Acanthamoeba spp., Balamuthia mandrillaris, and Naegleria fowleri. J Clin Microbiol 2006; 44: 3589-3595.

45. Aichelburg AC, Walochnik J, Assadian O, Prosch H, Steuer A, Perneczky G, Visvesvara GS, Aspöck H, Vetter N. Successful treatment of disseminated Acanthamoeba sp. infection with miltefosine. Emerg Infect Dis 2008; 14: 1743-1746.

46. Zamora A, Henderson H, Swiatlo E. Acanthamoeba encephalitis: a case report and review of therapy. Surg Neurol Int 2014; 5: 68.

47. Maycock NJ, Jayaswal R. Update on Acanthamoeba keratitis: diagnosis, treatment, and outcomes. Cornea 2016; 35: 713-720.

48. Carnt N, Robaei D, Minassian DC, Dart JK. Acanthamoeba keratitis in 194 patients: risk factors for bad outcomes and severe inflammatory complications. Br J Ophthalmol 2018; 102: 1431-1435.

49. Parija SC, Dinoop KP, Venugopal H. Management of granulomatous amebic encephalitis: Laboratory diagnosis and treatment. Trop Parasitol 2015; 5: 23-28.

50. Dua HS, Aralikatti A, Said DG. Rapid diagnosis of Acanthamoeba keratitis. Br J Ophthalmol 2009; 93: 1555-1556.

51. Petry F, Torzewski M, Bohl J, Wilhelm-Schwenkmezger T, Scheid P, Walochnik J, Michel R, Zöller L, Werhahn KJ, Bhakdi S, Lackner KJ. Early diagnosis of Acanthamoeba infection during routine cytological examination of cerebrospinal fluid. J Clin Microbiol 2006; 44: 1903-1904.

52. Bloch KC, Schuster FL. Inability to make a premortem diagnosis of Acanthamoeba species infection in a patient with fatal granulomatous amebic encephalitis. J Clin Microbiol 2005; 43 : 3003-3006.

53. Khan NA. Granulomatous amoebic encephalitis: clinical diagnosis and management. Am J Infect Dis 2005; 1: 79-83.

54. Lindsay RG, Watters G, Johnson R, Ormonde SE, Snibson GR. Acanthamoeba keratitis and contact lens wear. Clin Exp Optom 2007; 90: 351-360.

55. Brown AC, Ross J, Jones DB, Collier SA, Ayers TL, Hoekstra RM, Backensen B, Roy SL, Beach MJ, Yoder JS, Acanthamoeba keratitis investigation team. Risk factors for Acanthamoeba keratitis-a multistate case-control study, 2008-2011. Eye Contact Lens 
2018; 44 (suppl): 173-178.

56. Johnston SP, Sriram R, Qvarnstrom Y, Roy S, Verani J, Yoder J, Lorick S, Roberts J, Beach MJ, Visvesvara G. Resistance of Acanthamoeba cysts to disinfection in multiple contact lens solutions. J Clin Microbiol 2009; 47: 2040-2045.

57. Siddiqui R, Aqeel Y, Khan NA. The development of drugs against Acanthamoeba infections. Antimicrob Agents Chemother 2016; 60: 6441-6450.

58. Khan NA, Ong TY, Siddiqui R. Targeting brain-eating amoebae infections. ACS Chem Neurosci 2017; 8: 687-688.

59. Nuprasert W, Putaporntip C, Pariyakanok L, Jongwutiwes S. Identification of a novel T17 genotype of Acanthamoeba from environmental isolates and T10 genotype causing keratitis in Thailand. J Clin Microbiol 2010; 48: 4636-4640.

60. Wannasan A, Uparanukraw P, Songsangchun A, Morakote N. Potentially pathogenic free-living amoebae in some flood-affected areas during 2011 Chiang Mai flood. Rev Inst Med Trop Sao Paulo 2013; 55: 411-416.

61. Buppan, P., Meeboon, C., Klamsiri, T., Promyuttana, W., Koamornsup, W., Kosuwin, R.\&Srimee, P. Survey of Acanthamoeba spp. in Water Samples from the Public Park of Thailand. J Res Unit Sci Technol Environ Learning 2018; 5: 36-45.

62. Wannasan A, Chaiwong P, Bunchoo M, Morakote N. Occurence of thermotolerant Naegleria and Acanthamoeba in some natural water sources in Chiang Mai. Chiang Mai Med J 2009; 48: $117-124$.

63. Yaicharoen R, Ngrenngarmlert W, Thongmee P, Damsaman W. Survey of Acanthamoeba spp. in dust from Bangkok and suburban areas. Bull Chiang Mai Assoc Med Sci 2007; 40: 46.

64. Anisah N, Yusof S, Rahimah I, Norhayati M. Isolation of Acanthamoeba spp. from domestic water tap. Trop Biomed 2003; 20: 87-89.

65. Gabriel S, Khan NA, Siddiqui R. Occurrence of free-living amoebae (Acanthamoeba, Balamuthia, Naegleria) in water samples in Peninsular Malaysia. J Water Health 2019; 17: 160-171.

66. Chan LL, Mak JW, Low YT, Koh TT, Ithoi I, Mohamed SM. Isolation and characterization of Acanthamoeba spp. from air-conditioners in Kuala Lumpur, Malaysia. Acta Trop 2011; 117: 2330.

67. Onichandran S, Kumar T, Salibay CC, Dungca JZ, Tabo HA, Tabo N, Tan TC, Lim YA, Sawangjaroen N, Phiriyasamith S, Andiappan H, Aandiappan H, Ithoi I, Lau YL, Nissapatorn V. Waterborne parasites: a current status from the Philippines. Parasit Vectors 2014; 7: 244.

68. Lim BX, Koh VT, Ray M. Microbial characteristics of post-traumatic infective keratitis. Eur J Ophthalmol 2018; 28: 13-18.

69. Gunawan PI, Idarto A, Saharso D. Acanthamoeba infection in a drowning child. Ethiop J Health Sci 2016; 26: 289-292.

70. Wanachiwanawin D, Booranapong W, Kosrirukvongs P. Clinical features of Acanthamoeba keratitis in contact lens wearers and non-wearers. Southeast Asian J Trop Med Public Health 2012; 43: 549.

71. Anshu A, Parthasarathy A, Mehta JS, Htoon HM, Tan DT. Out- comes of therapeutic deep lamellar keratoplasty and penetrating keratoplasty for advanced infectious keratitis: a comparative study. Ophthalmol 2009; 116: 615-623.

72. Por YM, Mehta JS, Chua JL, Koh TH, Khor WB, Fong AC, Lim JW, Heng WJ, Loh RS, Lim L, Tan DT. Acanthamoeba keratitis associated with contact lens wear in Singapore. Am J Ophthalmol 2009; 148: 7-12.

73. Agahan AL, Lim RB, Valenton MJ. Successful treatment of Acanthamoeba keratitis without anti-amoebic agents. Ann Acad Med Singapore 2009; 38: 175-176.

74. Sirikul T, Prabriputaloong T, Smathivat A, Chuck RS, Vongthongsri A. Predisposing factors and etiologic diagnosis of ulcerative keratitis. Cornea 2008; 27: 283-287.

75. Parthasarathy A, Tan DT. Deep lamellar keratoplasty for Acanthamoeba keratitis. Cornea. 2007; 26: 1021-1023.

76. Siripanth C. Amphizoic amoebae: pathogenic free-living protozoa; review of the literature and review of cases in Thailand. J Med Assoc Thai 2005; 88: 701-707.

77. Sukthana Y, Rigunti M, Siripanth C, Kusolsuk T, Chintrakarn C, Kulpaditharom B. An exotic sinusitis. Trans R Soc Trop Med Hyg 2005; 99: 555-557.

78. Lim L, Wei RH. Laser in situ keratomileusis treatment for myopia after Acanthamoeba keratitis. Eye Contact Lens 2004; 30: 103-104.

79. Cheng CL, Ling ML, Lim L. A case series of Acanthamoeba keratitis in Singapore. Singapore Med J 2000; 41: 550-553.

80. Jongwutiwes S, Pariyakanok L, Charoenkorn M, Yagita K, Endo T. Heterogeneity in cyst morphology within isolates of Acanthamoeba from keratitis patients in Thailand. Trop Med Inter Health 2000; 5: 335-340.

81. Kosrirukvongs P, Wanachiwanawin D, Visvesvara GS. Treatment of Acanthamoeba keratitis with chlorhexidine. Ophthalmol 1999; 106: 798-802.

82. Kamel AM, Norazah A. First case of Acanthamoeba keratitis in Malaysia. Trans R Soc Trop Med Hyg 1995; 89: 652.

83. Sangruchi T, Martinez AJ, Visvesvara GS. Spontaneous granulomatous amebic encephalitis: report of four cases from Thailand. Southeast Asian J Trop Med Public Health 1994; 25: 309.

84. Thamprasert K, Khunamornpong S, Morakote N. Acanthamoeba infection of peptic ulcer. Ann Trop Med Parasitol 1993; 87: 403-405.

85. Kusrini E, Hashim F, Gunawan C, Mann R, Azmi WN, Amin NM. Anti-amoebic activity of acyclic and cyclic-samarium complexes on Acanthamoeba. Parasitol Res 2018; 117: 1409-1417.

86. Kusrini E, Hashim F, Azmi WN, Amin NM, Estuningtyas A. A novel antiamoebic agent against Acanthamoeba sp.-A causative agent for eye keratitis infection. Spectrochim Acta A Mol Biomol Spectrosc. 2016; 153: 714-721.

87. Siddiqui R, Abjani F, Yeo CI, Tiekink ER, Khan NA. The effects of phosphanegold (I) thiolates on the biological properties of Acanthamoeba castellanii belonging to the T4 genotype. J Negat Results Biomed 2017; 16: 6.

88. Siddiqui R, Aqeel Y, Khan NA. The use of dimethyl sulfoxide in 
contact lens disinfectants is a potential preventative strategy against contracting Acanthamoeba keratitis. Cont Lens Anterior Eye 2016; 39: 389-393.

89. Ibrahim M, Mohd Yusof M, Amin N. Anti-amoebic properties of carbonyl thiourea derivatives. Molecules 2014; 19: 51915204.

90. Boonman N, Prachya S, Boonmee A, Kittakoop P, Wiyakrutta S, Sriubolmas N, Warit S, Dharmkrong-At Chusattayanond A. In vitro acanthamoebicidal activity of fusaric acid and dehydrofusaric acid from an endophytic fungus Fusarium sp. Tlau3. Planta Med 2012; 78: 1562-1567.

91. Roongruangchai J, Sookkua T, Kummalue T, Roongruangchai K. Pouzolzia indica methanolic extract fraction 2 and povidone-iodine induced changes in the cyst of Acanthamoeba spp.: light and electron microscopic studies. J Med Assoc Thai 2011; 92: 1492.

92. Roongruangchai K, Kummalue T, Sookkua T, Roongruangchai J. Comparison of Pouzolzia indica methanolic extract and Virkon ${ }^{\circledR}$ against cysts of Acanthamoeba spp. Southeast Asian J Trop Med Public Health 2010; 41: 776.

93. Anwar A, Masri A, Rao K, Rajendran K, Khan NA, Shah MR, Siddiqui R. Antimicrobial activities of green synthesized gumsstabilized nanoparticles loaded with flavonoids. Sci Rep 2019; 9: 3122.

94. Mahboob T, Nawaz M, Tian-Chye T, Samudi C, Wiart C, Nissapatorn V. Preparation of poly (dl-lactide-co-glycolide) nanoparticles encapsulated with periglaucine A and betulinic acid for in vitro anti-Acanthamoeba and cytotoxicity activities. Pathogens 2018; 7: 62.

95. Mahboob T, Azlan AM, Shipton FN, Boonroumkaew P, Azman NS, Sekaran SD, Ithoi I, Tan TC, Samudi C, Wiart C, Nissapatorn $\mathrm{V}$. Acanthamoebicidal activity of periglaucine A and betulinic acid from Pericampylus glaucus (Lam.) Merr. in vitro. Exp Parasitol 2017; 183: 160-166.

96. Anwar A, Siddiqui R, Shah MR, Khan NA. Gold nanoparticleconjugated cinnamic acid exhibits antiacanthamoebic and antibacterial properties. Antimicrob Agents Chemother 2018; 62: e00630-18.

97. Mahboob T, Azlan AM, Tan TC, Samudi C, Sekaran SD, Nissapatorn V, Wiart C. Anti-encystment and amoebicidal activity of
Lonicera japonica Thunb. and its major constituent chlorogenic acid in vitro. Asian Pac J Trop Med 2016; 9: 866-871.

98. Akbar N, Siddiqui R, Iqbal M, Sagathevan K, Khan NA. Gut bacteria of cockroaches are a potential source of antibacterial compound(s). Lett Appl Microbiol 2018; 66: 416-426.

99. Sampaotong T, Roongruangchai J, Roongruangchai K. Viability and morphological changes of Acanthamoeba spp. cysts after treatment with effective microorganisms (EM). J Parasit Dis 2016; 40: 369-373.

100. Anwar A, Siddiqui R, Shah MR, Khan NA. Gold Nanoparticles Conjugation Enhances Antiacanthamoebic properties of nystatin, fluconazole and amphotericin B. J Microbiol Biotechnol 2019; 29: 171-177.

101. Anwar A, Siddiqui R, Hussain MA, Ahmed D, Shah MR, Khan NA. Silver nanoparticle conjugation affects antiacanthamoebic activities of amphotericin B, nystatin, and fluconazole. Parasitol Res 2018; 117: 265-271.

102. Anwar A, Rajendran K, Siddiqui R, Raza Shah M, Khan NA. Clinically approved drugs against CNS diseases as potential therapeutic agents to target brain-eating amoebae. ACS Chem Neurosci 2019; 10: 658-666.

103. Siddiqui R, Lakhundi S, Iqbal J, Khan NA. Effect of non-steroidal anti-inflammatory drugs on biological properties of Acanthamoeba castellanii belonging to the T4 genotype. Exp Parasitol 2016; 168: 45-50.

104. Siddiqui R, Saleem S, Khan NA. The effect of peptidic and nonpeptidic proteasome inhibitors on the biological properties of Acanthamoeba castellanii belonging to the T4 genotype. Exp Parasitol 2016; 168: 16-24.

105. Nacapunchai D, Phadungkul K, Kaewcharus S. In vitro effect of artesunate against Acanthamoeba spp. Southeast Asian J Trop Med Public Health 2003; 33: 49-52.

106. Siddiqui R, Jeyamogan S, Ali SM, Abbas F, Sagathevan KA, Khan NA. Crocodiles and alligators: antiamoebic and antitumor compounds of crocodiles. Exp Parasitol 2017; 183: 194 200.

107. Nakisah MA, Muryany MI, Fatimah H, Fadilah RN, Zalilawati MR, Khamsah S, Habsah M. Anti-amoebic properties of a Malaysian marine sponge Aaptos sp. on Acanthamoeba castellanii. World J Microbiol Biotechnol 2012; 28: 1237-1244. 
